\title{
A comparison of sensory evaluation and an electronic nose assay in the assessment of aroma in dry hopped beers
}

\author{
Jana Štefániková ${ }^{*}$, Veronika Nagyová ${ }^{1}$, Matej Hynšt ${ }^{1}$, Dominika Kudláková2, Július Árvay ${ }^{3}$, Štefan Dráb² \\ 1 AgroBioTech Research Centre, Slovak University of Agriculture \\ in Nitra, Tr. A. Hlinku 2, 94976 Nitra, Slovakia \\ 2 Department of Technology and Quality of Plant Products, \\ Faculty of Biotechnology and Food Sciences, Slovak University \\ of Agriculture in Nitra, Tr. A. Hlinku 2, 94976 Nitra, Slovakia \\ 3 Department of Chemistry, Faculty of Biotechnology and Food \\ Sciences, Slovak University of Agriculture in Nitra, \\ Tr. A. Hlinku 2, 94976 Nitra, Slovakia \\ ${ }^{*}$ Corresponding author: jana.stefanikova@uniag.sk, \\ stefan.drab@uniag.sk
}

\begin{abstract}
The aim of this work was to compare sensory evaluation and electronic nose technology used to assess aromas in dry hopped beers. An electronic nose based on gas chromatography was used for the first time. Hops varieties Amarillo, Cascade, Chinook, Kazbek and Mandarina Bavaria were used for the production of dry hopped beers and the Sladek variety was used for the control sample. The basic characteristics of the beers were determined, and the sensory evaluation performed by selected assessors was compared to the sensory assay using an electronic nose. Assessment of the aroma profile of dry hopped beers shows that the basic flavours of these beers, such as worty, yeasty and hoppy, were suppressed. Compared to the control sample, a significant grapefruit flavour was noted by the evaluators in Kazbek and Chinook beer samples. The most prominent determinant, compared to the control sample, was in general the citrus aroma. Based on the results of the principal component analysis, it can be concluded that there were statistically significant differences between the individual dry hopped beers and between them and the control sample with the exception of beers dry hopped with hops of the Amarillo and Cascade variety, which was also confirmed by the results of sensory evaluation (approximately the same scoring of the monitored descriptors).
\end{abstract}

Key words: beer, dry hopping, electronic nose, hops

\section{Introduction}

Dry hopping is a method used to achieve a more intensified hop aroma of beer. It is known that during wort boiling, aromatic compounds of hops are subjected to evaporation and strong oxidation. Consequently, they are also affected during the fermentation process when they are absorbed by the foam and yeast cells, then reduced, hydrolysed, esterified, or even undergoing transformation (Takoi et al., 2016). Addition of hop products to the finished beer causes the volatile aromatic compounds to remain in the beer as they do not enter the oxidation process, and therefore they significantly affect the sensory profile of such a beer. Likewise, bitter acids are not subjected to isomerization to iso- $\alpha$-acids as they are in the hop processing during wort boiling (Oladokun and Cook, 2016). In recent years, there has been a significant increase in the interest in specific-flavoured hops varieties, 
which are used mainly by small breweries to produce top-fermented beer specialties. The highest increase of interest in these beer types was in the USA, from where it later spread to the world (Farago et al., 2013).

Hop extracts consist of the resin fraction responsible for the bitter taste of the beer and of the volatile fraction that affects the beer aroma. The hop resin fraction is one of the most important components of the brewing sector and contains mainly the $\alpha$ - and $\beta$-acids. Products that originate from these acids, which are formed during the wort boiling phase, are the source of the typical bitter taste of beer; they stabilize the beer foam and increase the biological durability of the beer due to antiseptic effects (Ravindran, 2017). The hop oils (volatile fraction), in particular, are responsible for the flavour of hops and of finished beers, and they are a complex mixture of several hundreds of natural substances that varies in its chemical composition and in percent representation of particular substances. The overall aroma of a hop variety can be understood as a composition of several essential flavour characteristics, such as fruity, floral, citrus, herbal or spicy. The most important carrier of citrus fragrance is the monoterpene limonene, while the floral character is characterized by the terpene alcohols linalool, geraniol and farnesol. Spicy aroma is associated with substances such as farnesene, caryophyllene, humulone, etc. (Nesvadba et al., 2013).

The quality of the hops is assessed all throughout the growing and processing, ranging from hop maturation, harvesting, processing of hop products, to the brewery use. In the past, the hop quality was evaluated solely by sensory rating; including for example smell, the amount and colour of lupulin, health condition and the rate of hop heads damage by diseases or pests. In the second half of the 20 th century, however, advances in analytical chemistry made it possible to gradually introduce into the quality assessment uniform analytical methods such as the determination of the content of bitter acids and prenylflavonoids and xanthohumol by liquid chromatography and hop oils by gas chromatography (Ježek et al., 2015).

The sensory panel of evaluators records the perception of the tested beer by several senses, using the odour to detect volatile organic compounds derived from beer. Yet, the subjective evaluation underlies the variability not only within different panel formations, but also at the same time within the same evaluators depending on their actual conditions. To become an evaluating expert, an evaluator has to pass through an intensive training, demanding in both time and money. Due to the interaction of volatile substances and physiological state of beer, the correlation between sensory evaluation results and chemical analysis is not always easy and clear (Stucky and Mcdaniel, 2017). At present, confirmation of the results of sensory evaluation by determining the aromatic profile using electronic nose (e-nose) is widespread. E-nose is a device designed to detect odours by sensory field (Delgado-Rodríguez et al., 2012). It works on the principle of gas chromatography that is able to detect the presence of low concentrations of aromatic compounds in real time of several minutes and identify them by Kovat's retention indices compared to the NIST library. In order to obtain relevant information from the sample analysis, statistical techniques of multivariate analysis are most commonly used (Buratti et al., 2018). E-nose is used in many industries and for a variety of applications such as quality control, production process monitoring, durability assessment, origin and originality assessment (Wilson and Baietto, 2009; Magdalena et al., 2014; Li et al., 2017).

The aim of this work was to prepare top-fermented beers by the dry hopping process applying different hop varieties; and compare sensory evaluation and electronic nose assay of aromas in dry hopped beers. Samples of beers were subjectively evaluated by selected assessors by means of an evaluation sheet and the impact of bitterness in relation to the content of bitter substances was investigated. Sensory assessment by assessors was compared to the determination of aromatic profiles by electronic nose.

\section{Material and methods}

\subsection{Sample preparation}

Brewing of beer was performed under the conditions of a school experimental brewery in the AgroBioTech Research Centre area. Pilsner 68.38\%, Viennese 8.55\%, Bavarian $6.84 \%$, caramel $7.69 \%$ and wheat types of malt $8.55 \%$ were used for $20 \mathrm{~L}$ wort production by infusion mashing in such a ratio that the actual wort extract reached $12.0 \%$ by weight. During the 80 -minute wort boiling, type 90 hop pellets of the Czech variety Sladek ( $\alpha$-acids content $7.49 \%$ by weight) were added in the fifth minute in such an amount that the bitterness of wort reached 30.0 IBU. The wort so prepared was cooled to the fermentation temperature of $12{ }^{\circ} \mathrm{C}$ and was inoculated with Saccharomyces cerevisiae var. cerevisiae (Safbrew S-33, Fermentis) yeast appropriate for top-fermentation. Primary fermentation was running for six days at $15{ }^{\circ} \mathrm{C}$. After the main fermentation process, the young beer was filled into $500 \mathrm{ml}$ glass bottles, where the secondary fermentation was carried out with the addition of hops of a certain variety (Amarillo, Cascade, Chinook, Kazbek and Mandarina Bavaria) in the form of type 90 pellets in an amount of $2.00 \mathrm{~g} / \mathrm{L}$ and 
without the addition of hops (control samples). Tables 1-2 show a more detailed description of the hop samples. Secondary fermentation was carried out for two weeks at $6^{\circ} \mathrm{C}$. A total of 6 samples in $500 \mathrm{ml}$ glass bottles (i.e. a sum of 12 samples) were prepared in duplicate under the same experimental conditions.

\subsection{Determination of basic parameters}

Prior to the measurement, a $150 \mathrm{ml}$ volume of beer sample was degassed (freed of $\mathrm{CO}_{2}$ ) and filtered through a pleated filter MN 614 1⁄/4 Ø 320 mm (MACHEREY-NAGEL, Germany). Alcohol content was determined based on the methods of EBC 9.43.2 Analytics and 9.2.6 EBC Analytics (EBC-Analytica, 2010) using the Alcolyzer Beer with DMA 4500M Densitometric Module (Anton Paar GmbH, Austria). The apparent and the original wort extract were calculated based on the determined alcohol content of the beer according to the specific calculations given in the EBC Method 9.4 (EBC-Analytica, 2010). The samples were measured in duplicates, and thus the results demonstrate average values of four measurements.

Determination of the bitter substances content was performed according to the 9.8 EBC Analytics methodology (EBC-Analytica, 2010). After acidification of the beer with hydrochloric acid ( $\mathrm{HCl})$, the bitter substances were extracted into a suitable isooctane solvent. Extraction of the bitter substances was supported by shaking at $20{ }^{\circ} \mathrm{C}$ and the resulting phases were subsequently separated by centrifugation (Rotina 420 centrifuge, Hettich, Germany) for 3 minutes at $3000 \mathrm{rpm}$. After shaking and centrifugation of the samples, light absorbance at $275 \mathrm{~nm}$ (UV/VIS spectrophotometer Cary 60, Agilent Technologies, USA) was measured in the samples having the bitter substances dissolved in isooctane and compared to the reference pure isooctane (A275) absorbance. The results are average values of four measurements as the samples were measured in duplicates. The resulting value of bitterness expressed in international bitter units IBU (mg of iso- $\alpha$-acids in 1 litre of beer) can be obtained from the following relationship:

$$
\text { bitterness }(I B U)=50 \times A_{275}
$$

\subsection{Sensory evaluation}

Beer samples were judged by subjective evaluation of a sensory panel of 12 trained evaluators ( 4 men +8 women) by means of an evaluation sheet. Two hours before sensory evaluation, the beers were taken out of the refrigerator. Each sample was rated in each selected descriptor

Table 1 Description of the hop samples; the bitter acids content and the content of total oils and myrcene (Lutz et al., 2013; Van Holle et al., 2017; Lafontaine and Shellhammer, 2018; Hoplist, 2019; Krofta et al., 2019)

\begin{tabular}{|c|c|c|c|c|c|}
\hline & Chinook & Amarillo & Cascade & $\begin{array}{c}\text { Mandarina } \\
\text { Bavaria }\end{array}$ & Kazbek \\
\hline Alpha acids (wt. \%) & $12-14$ & $8-11$ & $4.5-7$ & $7-10$ & $5-8$ \\
\hline Beta acids (wt. \%) & $3-4$ & $6-7$ & $4.8-7$ & $4-7$ & $4-6$ \\
\hline Cohumulone (wt. \% of alpha acids) & $29-34$ & $21-24$ & $33-40$ & $28-35$ & $35-40$ \\
\hline Myrcene (wt. \% of total oils) & $35-40$ & $68-70$ & $45-60$ & $70-72$ & $35-50$ \\
\hline Total oils (ml/100 g) & $1.5-2.7$ & $1.5-1.9$ & $0.7-1.4$ & $2.1-2.3$ & $1-2$ \\
\hline
\end{tabular}

Table 2 Description of the hop samples; dominant aromatic compounds and typical aromas (Takoi et al., 2016; Mikyška et al., 2017; Van Holle et al.,2017; Vollmer et al., 2018)

\begin{tabular}{|c|c|c|}
\hline Hop & Dominant aromatic compounds & Typical aroma \\
\hline Amarillo & $\begin{array}{c}\text { methyl octane, } \beta \text {-myrcene, linalool, geraniol, } 2 \text {-undekanone, } \beta \text {-car- } \\
\text { yophyllene, } \alpha \text {-humulene, } \beta \text {-farnesene }\end{array}$ & citrus, floral, tropical \\
\hline Chinook & $\begin{array}{c}\text { 2-furanmethanol, butyrolactone, linalool, geraniol, cis-geranic } \\
\text { acid methyl ester, n-decanoic acid, } \beta \text {-myrcene, } \beta \text {-caryophyllene, } \\
\text { a-humulene, nerol, geraniol, geranial, methyl geranate, caryophyl- } \\
\text { lene oxide }\end{array}$ & $\begin{array}{l}\text { fruity, bread, floral, musty, trop- } \\
\text { ic, anise, menthol, sweat }\end{array}$ \\
\hline Cascade & $\begin{array}{c}\text { isoamyl butyrate, benzene acetaldehyde, linalool, cis-geranic acid } \\
\text { methyl ester, geranyl acetate, } \beta \text {-myrcene, } \beta \text {-caryophyllene, } a \text {-hu- } \\
\text { mulene, } \beta \text {-farnesene, nerol, geraniol, geranial, methyl geranate, } \\
\text { caryophyllene oxide }\end{array}$ & $\begin{array}{l}\text { strawberry, tropic, fruity, anise, } \\
\text { musty, menthol, floral, sweat, } \\
\text { cheese, earthy }\end{array}$ \\
\hline Kazbek & $\begin{array}{l}\text { myrcene, linalool, cis-geraniol, } \beta \text {-caryophyllene, } \alpha \text {-humulene, } \\
\beta \text {-farnesene, } \beta \text {-caryophyllene epoxide, farnesol }\end{array}$ & $\begin{array}{l}\text { fruity, herbal, spicy, grassy, } \\
\text { woody }\end{array}$ \\
\hline Mandarina Bavaria & $\begin{array}{l}\text { linalool, nerol, } \beta \text {-citronellol, cis-linalool oxide, geraniol, isobutyl } \\
\text { isobutyrate, isoamyl isobutyrate, ethyl heptanoate, geranyl ace- } \\
\text { tate, } \beta \text {-ionone, } 2 \text {-methylbutyl isobutyrate }\end{array}$ & fruity, lime, apple, apricot, floral \\
\hline
\end{tabular}


with a corresponding number of points in the intensity scale from 1 (threshold) to 9 (intense). The evaluators were asked to list the main odour and aroma impressions out of pre-defined aroma characteristics (hop, malt, yeast, spicy, floral, citrus, grapefruit, other) and flavour characteristics (sweet, caramel, citrus, spicy, yeast, general impression) were chosen based on the characteristics of hop varieties found in available literature (Kenny and Zimmermann, 1986; Nickerson and Van Engel, 1992; Kishimoto et al., 2006; Nesvadba et al., 2012; Lutz et al., 2013; Cibaka et al., 2015; Schnaitter et al., 2016) in order to detect differences in beer taste and aroma. The evaluators were also asked to give a score ranging from 1-9 for the bitterness intensity (smoothness - pleasant, not spiky and harsh; first impression - the intensity of bitterness perceived after $10 \mathrm{~s}$; after-bitterness - $30 \mathrm{~s}$ after swallowing the beer) (Oladokun et al., 2017; Van Holle et al., 2017). Each dry hopped beer in its replicate brews and control sample were tasted twice by each evaluator. The replicates were tasted in different sessions. The resulting value corresponds to the trimmed average of a given parameter, i.e. the maximum and minimum value is always excluded, and the average is calculated from the remaining values.

\subsection{Sensory analysis using e-nose}

Samples of $4.00 \mathrm{~g}$ weight were placed into $20 \mathrm{ml}$ headspace vial with PTFE/Sil septum (Agilent Technologies, USA) magnetic cap. The samples thus prepared were stirred for 15 minutes at $50{ }^{\circ} \mathrm{C}$ in a shaker, which is part of the e-nose headspace autosampler (Combi Pal, Alpha M.O.S., France). From the saturated air above the sample level, $5 \mathrm{ml}$ was collected using a headspace needle and injected into the e-nose injector at $200{ }^{\circ} \mathrm{C}$.

The e-nose (Heracles II, Alpha M.O.S., France) analysis previously described by Štefániková et al. (2019) was used for sensory evaluation of the beer samples.

A semi-quantitative evaluation was achieved by comparing Kovat's retention indexes. Measurement evalua- tion was performed using the PCA (Principal Component Analysis) method. Samples were measured in duplicates; the results are thus average values of four measurements.

\section{Results and discussion}

We prepared the wort hopped with the Sladek hop variety (12.0 wt. \% and 30.0 IBU). Subsequently, primary fermentation was carried out for six days and basic parameters were determined in the young beer so produced (Table 3 ). Following the basics of the beer colour value ( 32.4 j. EBC), a young semi-dark beer was prepared according to the valid Decree no. 30/2014 (2014), where the colour of semi-dark beer is set to be from 19.0 to 39.0 EBC units. Determined parameters such as the alcohol content of 4.09 vol. \% and bitterness of 29.2 IBU matched the parameters of the top-fermented beer English Pale Ale - Extra Special/Strong Bitter (Pavsler and Buiatti, 2009).

After secondary fermentation, during which dry hopping with 5 different hop varieties (Amarillo, Cascade, Chinook, Kazbek and Mandarina Bavaria) took place, the basic parameters of the beers and bitterness (Table 3) and sensory evaluation by the assessors (aroma profiles are shown in Figure 1, taste profiles are shown in Figure 2 ) were compared with the determination of aromatic profiles by e-nose (Figure 3). The alcohol content of dry hopped beers ( $4.10 \pm 0.03$ vol. \%) was not significantly different from that of young beer (4.09 vol. \%) or the beer used as a control sample (4.03 vol. \%). Based on the above results, it can be concluded that the hop varieties did not influence the secondary fermentation process, thus meeting our expectations.

Bitterness in young beer was determined at 29.2 IBU and its value after the secondary fermentation in the control sample remained unchanged. Bitterness of dry hopped beers increased depending on the hop variety (42.5-61.7 IBU). The highest value of bitterness was

Table 3 Determination of basic parameters in wort, young beer, dry hopped beers and control sample.

\begin{tabular}{|c|c|c|c|c|c|}
\hline \multicolumn{2}{|c|}{ Sample } & Alcohol (vol. \%) & Real extract (wt. \%) & Colour (EBC units) & Bitterness (IBU) \\
\hline \multicolumn{2}{|c|}{ Wort } & - & 12.13 & 40.7 & 30.0 \\
\hline \multicolumn{2}{|c|}{ Young beer } & 4.09 & 5.21 & 32.4 & 29.2 \\
\hline \multirow{4}{*}{ Dry hopped beer } & Chinook & 4.07 & 5.25 & 35.4 & 53.5 \\
\cline { 2 - 6 } & Amarillo & 4.09 & 5.25 & 35.0 & 50.9 \\
\cline { 2 - 6 } & Cascade & 4.05 & 5.24 & 35.0 & 52.0 \\
\cline { 2 - 6 } & Mandarina Bavaria & 4.10 & 5.25 & 35.3 & 61.7 \\
\cline { 2 - 6 } & Kazbek & 4.07 & 5.23 & 35.2 & 42.5 \\
\hline
\end{tabular}

The values represent the means of four replicate determinations (maximum relative standard deviation $\pm 5 \%$ ). 
determined in a sample of beer hopped with Mandarina Bavaria variety, which belongs to the bitter varieties (Prugar, 2008; Dobešová, 2010). Beer brewed with the bitter Amarillo variety had the bitterness value of 50.9 IBU, which was less than that determined in beer hopped with Cascade aromatic variety (52.0 IBU), or with high-content Chinook (53.5 IBU). The lowest content of bitter substances was determined in beer hopped with aromatic variety Kazbek.

The panel of evaluators tested the intensity of first impression bitterness, smoothness and perception of after-bitterness in produced samples on a scale of 1-9 points (Table 4). The beer hopped by Chinook had the most pronounced intensity of the first impression (5.3 points) and the most intense after-bitterness (5.5 points). On the contrary, the sample of beer hopped with Cascade had the significantly lowest rated intensity of the first impression (3.9 points), while in terms of bitterness it had a very similar value (52.0 IBU) to the Chinook-hopped beer (53.5 IBU). As the most "smooth" sample, the evaluators labelled the Kazbek-hopped beer (5.8 points), in which the lowest bitterness (42.5 IBU) was determined. In their study, Oberholster and Titus (2016) have shown that during dry hopping, the extraction of polyphenols

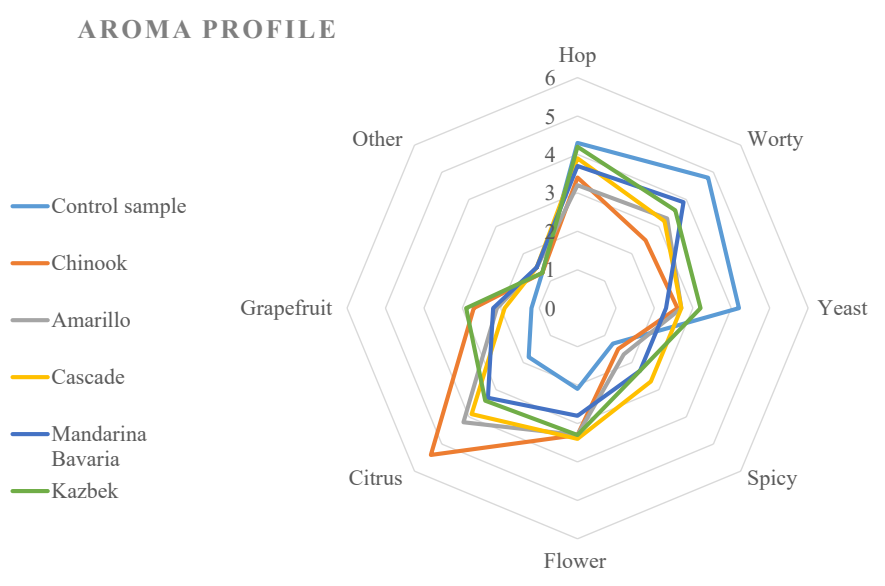

Figure 1 Evaluation of the aromatic profile of the control sample and of dry hopped beers prepared with different hop varieties (Kazbek, Mandarina Bavaria, Cascade, Amarillo, Chinook) rated by a panel of evaluators

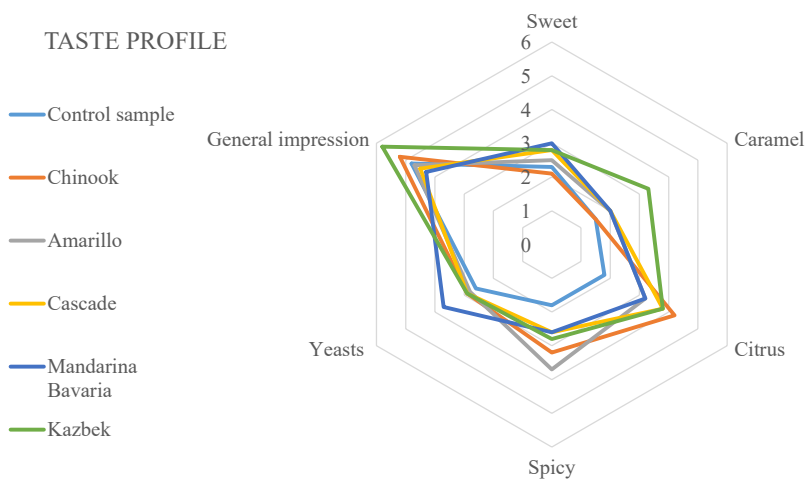

Figure 2 Evaluation of the taste profile of the control sample and of dry hopped beers prepared with different hop varieties (Kazbek, Mandarina Bavaria, Cascade, Amarillo, Chinook) rated by a panel of evaluators

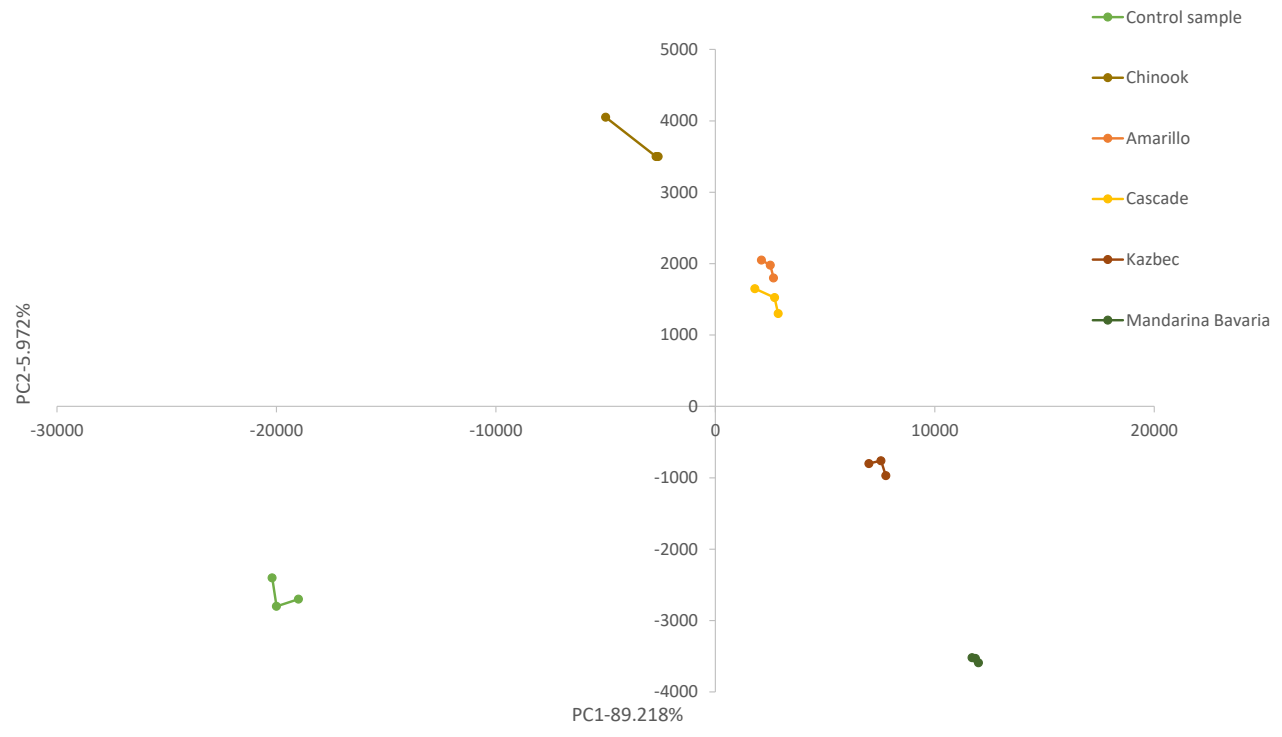

Figure 3 PCA analysis of the aromatic profile of the control sample and of dry hopped beers prepared with different hop varieties (Kazbek, Mandarina Bavaria, Cascade, Amarillo, Chinook) acquired by e-nose 
Table 4 Evaluation of bitterness intensity of the dry hopped beers and control sample by evaluators (range 1-9 points)

\begin{tabular}{|c|c|c|c|c|c|c|}
\hline \multirow{2}{*}{ Bitterness intensity descriptors } & \multicolumn{5}{|c|}{ Dry hopped beers } & \multirow{2}{*}{$\begin{array}{c}\text { Control } \\
\text { sample beer }\end{array}$} \\
\hline & $\begin{array}{c}\text { Mandarina } \\
\text { Bavaria }\end{array}$ & Chinook & Cascade & Amarillo & Kazbek & \\
\hline Smoothness & 5.1 & 5.0 & 4.6 & 4.8 & 5.8 & 4.8 \\
\hline Intensity of first impression & 5.0 & 5.3 & 3.9 & 5.2 & 4.2 & 4.1 \\
\hline After-bitterness & 4.6 & 5.5 & 4.6 & 4.9 & 3.8 & 4.4 \\
\hline
\end{tabular}

and other substances present in hops contributes to the bitter taste and astringency of the beer depending on their molecular weight. According to several studies (Almaguer et al., 2014; Algazzali and Shellhammer, 2016), the dry hopping process can also unintentionally affect perceived bitterness. These observations are explained by the presence of easily soluble oxidized $\alpha$-acids (humulinones), the bitterness intensity of which is $66 \%$ compared to that of the iso- $\alpha$-acids. The second explanation is that the volatile hop flavour compounds can improve the perception of bitterness and also adjust the quality of the bitterness, causing a multimodal interaction between taste and smell. According to Olšovská et al., (2017) the perceived bitterness of beer may not always correspond to the total iso- $\alpha$-acid content, since the individual compounds vary in bitterness and intensity.

Assessment of the aroma profile (Figure 1) of dry hopped beers using different hop varieties shows that the basic flavours of beer typical for the commonly produced top-fermented beer (control sample) such as worty, yeasty and hoppy were suppressed. Likewise, other flavours have become more intense depending on the hop variety applied in the beer making process. Compared to the control sample, significant grapefruit flavour was noted by the evaluators in Kazbek and Chinook beer samples. The most prominent determinant, compared to the control sample, was in general the citrus aroma (3.3-5.4 points). This aroma was most intense in the Chinook beer, in which significant amounts of linalool and geraniol, considered citrus-floral flavour compounds, were determined by the available literature (Lafontaine and Shellhammer, 2018; Vollmer et al., 2018).

Floral aroma was another significant aroma in dry hopped beers compared to the control sample. The highest intensity of floral aroma was observed in the Amarillo beer sample. The spicy aroma was, in general, the least intensive (1.5-2.7 points) in the evaluation of dry hopped beers. Several studies (Van Holle et al., 2017; Vollmer et al., 2018; Mikyška et al., 2018) reported on the preparation of beers hopped with the same hop varieties as the ones investigated in our study. Those studies also defined the dominant aroma compounds with their typical flavours, as well as the method of their detection. On comparing the results with the available literature, it can be stated that samples of dry hopped Kazbek (Mikyška et al., 2018; Krofta et al., 2019), Mandarina Bavaria (Takoi et al., 2016), Amarillo (Van Holle et al., 2017), Cascade and Chinook (Vollmer et al., 2018) reflected the major flavour components of these varieties evoking floral, spicy or citrus flavour.

In comparison to the control sample, the prevailing flavours in monitored samples were as follows: citrusy (3.2-4.2 points; max. value for Chinook beer), spicy (2.63.7 points; max. value for Amarillo beer), yeasty (2.8-3.7; max. value for Mandarina Bavaria beer), but also caramel (1.5-3.3 points; max. value for Kazbek beer). Capturing the perception of the citrusy flavour may have been caused by the presence of compounds such as linalool, geraniol and $\beta$-citronellol, which induce the citrusy flavour especially in this triple combination (Takoi et al., 2010). Aroma compounds of hops, after addition of the hops to the finished beer, are protected from transformation and therefore can excel in beer (Takoi et al., 2016). At the same time, it is important to note that both in the beer production process and during its ripening, chemical transformations of aroma compounds occur, resulting in changes in the flavour intensity and the overall flavour of the beer, e.g. the formation of geranyl acetate as a derivative of geraniol after interaction with acetic acid (Takoi et al., 2010; Peltz, 2015).

The overall impression was also evaluated within the taste profile (Figure 2). Due to the flavour and taste preferences of the individual evaluation committee members it is difficult for the sensory evaluation to be carried out, as the overall impression is always a complex matrix of influence that a beer has on the evaluator (Mikyška et al., 2018). Beer sample hopped with Kazbek variety (5.8 points) was rated as the overall most pleasant sample, providing the beer with a citrusy-caramel taste. The least points were given to the beer sample hopped with Mandarina Bavaria (4.3 points) with a strong yeasty, citrusy and sweet flavour.

Organoleptic panels can give a lot of information about the characteristics of the beer samples, but this method has some drawbacks such as assessor fatigue and subjectivity. Beer flavour is conventionally detected through the combination of common analytical tools 
which are expensive and time consuming. To help solving these problems, an objective evaluation method using electronic nose has recently attracted particular attention. Sensory evaluation was compared with the analysis of the aromatic profile of samples using e-nose. Figure 3 shows principal component analysis (PCA) evaluation of aroma differences of beer samples. PCA clearly visualized the differences among individual samples. Based on the results of the statistical evaluation of the sensory analysis, it can be concluded that there were statistically significant differences between the samples hopped with hops of certain varieties compared with control sample. At the same time, it can be confirmed that statistically significant differences were also among the individual samples of dry hopping, with the exception of beers hopped with the varieties Amarillo and Cascade, which is also confirmed by the result of sensory evaluation (approximately the same scoring of the monitored descriptors).

A total of 59 compounds were determined in the e-nose analysis. For statistical evaluation, 17 compounds were selected with a discriminatory force of $\geq 0.9$ identified by NIST library based on the similarity of Kovat's retention indexes ( $\geq 80 \%$ ). Isoamyl acetate, known for its fresh banana, pear and malt aroma (Spedding, 2009), was determined as a statistically significant compound in a beer hopped with Chinook. Acetaldehyde, responsible for the ethereal, fresh and fruity aroma (Carpenter, 2016), was determined as a significant aromatic compound in samples hopped with Amarillo and Cascade varieties. The identification of other compounds did not meet the given criteria, thereby reducing the likelihood of successful identification. Electronic nose technology tries to detect the fingerprints of volatile compounds present in the headspace of samples. However, this screening tool employs principles (sensors, short GC columns) that are not very selective to particular kinds of compounds, thus preventing any real identification or quantification of individual compounds present in the samples (Ghasemi-Varnamkhasti et al., 2011). For a more accurate determination, it is recommended to use a different analytical method such as gas chromatography with FID or MS detector, complemented, for example, with an external calibration curve.

\section{Conclusion}

Semi-dark top-fermented beers hopped with various varieties of hops (Amarillo, Cascade, Chinook, Kazbek and Mandarina Bavaria) with an alcohol content of $4.10 \%$ by volume were prepared. For the first time we used electronic nose with short gas chromatography columns and flame-ionisation detectors for evaluating the aroma profile of dry hopped beers. We confirm a correlation between the data from an electronic nose with those from a human sensory panel. Advantages of the e-nose include high sensitivity, price and ease of use.

\section{Acknowledgements}

The work was performed with the support of the AgroBioTech Research Centre, built as part of the "AgroBioTech" Research Centre ITMS 26220220180 project.

\section{References}

Algazzali, V., Shellhammer, T. 2016. Bitterness Intensity of Oxidized Hop Acids: Humulinones and Hulupones. J. Am. Soc. Brew. Chem. 74(1): 36-43. https://doi.org/10.1094/ASBCJ-2016-1130-01

Almaguer, C., Schönberger, C., Gastl, M., Arendt, E. K., Becker, T. 2014. Humulus lupulus - a story that begs to be told. A review. J. Inst. Brew., 120(4), 289-314. https://doi.org/10.1002/jib.160

Buratti, S., Malegori, C., Benedetti, S., Oliveri, P., Giovanelli, G. 2018. E-nose, e-tongue and e-eye for edible olive oil characterization and shelf life assessment: A powerful data fusion approach. Talanta 182: 131-141. https://doi.org/10.1016/j.talanta.2018.01.096

Carpenter, D. 2016. Off-Flavour of the week: Acetaldehyde. https://beerandbrewing.com/off-flavor-of-the-week-acetaldehyde/ [2019-01-16].

Cibaka, M. L., Gros, J., Nizet, S., Collin, S. 2015. Quantitation of Selected Terpenoids and Mercaptans in the Dual-Purpose Hop Varieties Amarillo, Citra, Hallertau Blanc, Mosaic, and Sorachi Ace. J. Agr. Food Chem. 63(11): 3022-3030. https://doi.org/10.1021/jf5058556

Decree No. 30/2014 Z. z. Decree of the Ministry of Agriculture and Rural Development of the Slovak Republic of 31 January 2014 on beverage requirements (in its wording No 158/2016 Z. z. http://www.zakonypreludi.sk/zz/2014-30\#Top [2019-01-16]

Delgado-Rodríguez, M., Ruiz-Montoya, M., Giraldez, I., López, R., Madejón, E., Díaz, M. J. 2012. Use of electronic nose and GC-MS in detection and monitoring some VOC. Atmos. Environ. 51: 278-285. https:// doi.org/10.1016/j.atmosenv.2012.01.006

Dobešová, K. 2010. Technologicky významné chemické látky chmele (Technologically significant chemical compounds of hops). Bakalárska práca, Univerzita Tomáše Bati v Zlíne, Zlín. https://pdfs.semanticscholar.org/be81/5da314ca48b35a09e594c849c38e0ed05787. pdf [2019-01-16].

EBC-Analytica, EBC Analysis committee (2010), 5th ed. Section 9 Beer. Method 9.43.2 Specific Gravity of Beer using a Density Meter; 9.4 Original, Real and Apparent Extract and Original Gravity of Beer; 9.8 Bitterness of Beer, Fachverlag Hans Carl, Nürnberg.

Farago, J., Krofta, K., Pšenáková, I., Nesvadba, V., Faragová, N., Fehérová, N., Timko, J. 2013. Chemical composition of wild hops in Slovak Republic. The 4th International Scientific Conference Applied Natural Sciences 2013, 2-4. October 2013: Nový Smokovec, Slovakia. Book of abstracts. p. 84. (Ondrejovič, M. and Nemeček, P. Eds.), University of Sc. Cyril and Methodius in Trnava. ISBN 978-80-8105-501-0.

Ghasemi-Varnamkhasti, M., Mohtasebi, S. S., Rodriguez-Mendez, M L., Lozano, J., Razavi, S. H., Ahmadi, H. 2011. Review Potential application of electronic nose technology in brewery. Trends Food Sci. Tech. 22: 165-174. https://doi.org/10.1016/j.tifs.2010.12.005

Hoplist [online]. http://www.hopslist.com/hops/dual-purpose-hops/ chinook/ [2019-11-05]. 
Ježek, J., Klapal, I., Krofta, K., Nesvadba, V., Patzak, J., Pokorný, J., Svoboda, P., Veselý, F., Vostřel, J. 2015. Chmel 2015 Príručka pro pěstitele chmele. (Hop 2015 Handbook for hop growers). p. 152 Chmelařský institut s.r.o., Žatec. ISBN 978-80-86836-98-0. „in Czech“

Kenny, S. T., Zimmermann, C. E. 1986. Registration of „Chinook“ hop. Crop Sci. 26(1): 196-197. ISSN: 0011-183X.

Kishimoto, T., Wanikawa, A., Kono, K., Shibata, K. 2006. Comparison of the Odor-Active Compounds in Unhopped Beer and Beers Hopped with Different Hop Varieties. J. Agr. Food Chem. 54: 8855-8861. https:// doi.org/10.1021/jf061342c

Krofta, K., Patzak, J., Sedlák, T., Mikyška, A., Štěrba, K., Jurková, M., 2019. Kazbek - The first Czek aroma "flavour hops" variety: Characteristics and utilization. Kvasný průmysl 65: 72-83. https://doi. org/10.18832/kp2019.65.72

Lafontaine, S. R., Shellhammer, T. H. 2018. Sensory Directed Mixture Study of Beers Dry-Hopped with Cascade, Centennial, and Chinook. J. Am. Soc. Brew. Chem. 76(3): 199-208. https://doi.org/10.1080/036104 70.2018.1487747

Li, Q., Yu, X. Z., Xu, L. R., Gao, J. M. 2017. Novel method for the producing area identification of Zhonging Goji berries by electronic nose. Food Chem. 211: 1113-1119. https://doi.org/10.1016/j.foodchem.2016.11.049

Lutz, A., Kneidl, J., Kammhuber, K., Seigner, E. 2013. Breeding of special flavor hops to pave the way to the craft brewers. International Hop Growers' Convention (IHGC), Proceedings of the Scientific Commission, p. 21-24. Kiev, Ukraine. ISSN 1814-2206

Magdalena, S., Wisniewska, P., Dymerski, T., Namiesnik, J., Wardencki, W. 2014. Food analysis using artificial senses. J. Agr. Food Chem. 62(7): 1423-1448. https://doi.org/10.1021/jf403215y

Mikyška, A., Olšovská, J., Slabý, M., Štěrba, K., Čerenak, A., Košir, I. J., Pavlovič, M., Kolenc, Z., Krofta, K. 2018. Analytical and sensory profiles of Slovenian and Czech hop genotypes in single hopped beers. J. Inst. Brew. 124(3): 209-221. https://doi.org/10.1002/jib.494

Nesvadba, V., Henychová, A., Ježek, J., Kořen, J., Krofta, K., Malířová, I., Patzak, J., Polončíková, Z., Svoboda, P., Vašeš, V., Vostrel, J. 2013. Vývoj a tradice českých odrud chmele. (Development and tradition of Czech hop varieties). p. 104, Chmelařsky institut s.r.o., Žatec. ISBN 978-80-87357-11-8. "in Czech"

Nesvadba, V., Polončíková, Z., Henychová, A. 2012. Šlechtění chmele v České republice. (Hop breeding in the Czech Republic). Kvasný Prům. 58(2): 36-39. http://doi.org/10.18832/kp2012006 „in Czech“

Nickerson, G. B., Van Engel, E. L. 1992. Hop Aroma Component Profile and the Aroma Unit. J. Am. Soc. Brew. Chem. 50(3): 77-81.

Oberholster, A., Titus, M.B. 2016. Review: Impact of Dry Hopping on Beer Flavor Stability. Ann. Food Processing and Preserv. 1(1): 1004. https://doi.org/10.1002/jib.517

Oladokun, O., Cook, D. 2016. The impact of hop bitter acid and polyphenol profiles on the perceived bitterness of beer. Food Chem. 205: 212220. https://doi.org/10.1016/j.foodchem.2016.03.023

Oladokun, O., James, S., Cowley, T., Dehrmann, F., Smart, K., Hort, J., Cook, D. 2017. Perceived bitterness character of beer in relation to hop variety and the impact of hop aroma. Food Chem. 230: 215-224. https://dx.doi.org/10.1016/j.foodchem.2017.03.031
Olšovská, J., Čejka, P., Štěrba, K., Slabý, M., Frantík, F. 2017. Senzorická analýza piva. (Sensory analysis of beer). p. 146, Výzkumný ústav pivovarský a sladařský, a.s., Praha. ISBN: 978-80-86576-74-9. „in Czech“

Pavsler, A., Buiatti, S. 2009. Non-lager Beer. Beer in Health and Disease Prevention. (Preedy, V. R. Ed) p. 17-30, Academic print, Burlington. ISBN 978-0-12-373891-2.

Peltz, M. L. 2015. The Role of Alcohol Content on Sensory Aroma Detection Thresholds in Beer. Master thesis, Oregon State University, USA.

Prugar, J. 2008. Chmel. Kvalita rostlinných produktů na prahu 3. Tisíciletí. (Hop. The quality of plant products on the threshold of the 3rd millennium). p. 116-132, Výzkumný ústav pivovarský a sladařský ve spolupráci s komisí jakosti rostlinných produktů ČAZV, Praha. ISBN 978-80-86576-28-2. „in Czech“

Ravindran, P. N. 2017. The Encyclopedia of Herbs \& Spices. Bell and Bain Ltd, Glasgow. ISBN 978-1-78639-114-8.

Schnaitter, M., Wimmer, A., Kollmannsberger, H., Gastl, M., Becker, T. 2016. Influence of hop harvest date of the 'Mandarina Bavaria' hop variety on the sensory evaluation of dry-hopped top-fermented beer. J. Inst. Brew. 122: 661-669. https://doi.org/10.1002/jib.382

Spedding, G. 2009. The Oxford Companion to Beer definition of isoamylacetate. The New Brewer. https://beerandbrewing.com/dictionary/9Al9LHtPIN/isoamyl-acetate/ [2019-01-16].

Stucky, G. J., Mcdaniel, M. R. 2017. Raw hop aroma qualities by trained panel free-choice profiling. J. Am. Soc. Brew. Chem. 55(2): 65-72. doi. org/10.1094/ASBCJ-55-0065

Štefániková, J., Nagyová, V., Hynšt, M., Vietoris, V., Martišová, P., Nagyová, L. 2019. Application of electronic nose for determination of Slovak cheese authentication based on aroma profile. Potr. S. J. F. Sci. 13(1): 262-267. https://doi.org/10.5219/1076

Takoi, K., Itoga, Y., Koie, K., Kosugi, T., Shimase, M., Katayama, Y., Nakayama, Y., Watari, J. 2010. The Contribution of Geraniol Metabolism to the Citrus Flavour of Beer: Synergy of Geraniol and $\beta$-Citronellol Under Coexistence with Excess Linalool. J. Inst. Brew. 116(3): 251-260. https://doi.org/10.1002/j.2050-0416.2010.tb00428.x

Takoi, K., Tokita, K., Sanekata, A., Nakayanama, Y. 2016. Varietal Difference of hop-derived flavour compounds in late-hopeed/dry-hopped beers. Brew. Science, 69(1/2): 1-7.

Van Holle, A., Van Landschoot, A., Roldán-Ruiz, I., Naudts, D., De Keukeleire, D. 2017. The brewing value of Amarillo hops (Humulus lupulus L.) grown in northwestern USA: A preliminary study of terroir significance. J. Inst. Brew. 123(3): 312-318. https://doi.org/10.1002/ jib.433

Vollmer, D. M., Lafontaine, S. R., Thomas, H., Shellhammer, T. H. 2018. Aroma Extract Dilution Analysis of Beers Dry-Hopped with Cascade, Chinook, and Centennial. J. Am. Soc. Brew. Chem. 76(3): 190-198. https://doi.org/10.1080/03610470.2018.1487746

Wilson, A. D., Baietto, M. 2009. Applications and advances in electronic nose technologies. Sensors 9(7): 5099-5148. https://doi. org/10.3390/s90705099 